Journal Of Metallurgical Engineering And Processing Technology, Vol. 2,

N0. 2, February 2022, pp.39-46

P-ISSN: 2723-6854, E-ISSN: 2798-1037

\title{
PENGARUH KUAT ARUS TERHADAP KEKUATAN TARIK PADA PROSES PENGELASAN BAJA SM 400 B MENGGUNAKAN PROSES PENGELASAN SMAW DI PT.BARATA INDONESIA (Persero) DIVISI SUMBER DAYA AIR - TEGAL
}

\author{
Dyah Probowati. ${ }^{1}$, Margaretha Tri Budi Yuliana ${ }^{2}$ \\ E-mail : dyah.probowati@upnyk.ac.id ${ }^{1}$; margarethatby2307@gmail.com ${ }^{2}$ \\ Program Studi Teknik Metalurgi - Fakultas Teknologi Mineral \\ UPN "Veteran" Yogyakarta \\ Jl. Padjadjaran, Condongcatur, Yogyakarta 55283
}

\section{Intisari}

PT. Barata Indonesia (Persero) Divisi Sumber Daya Air Tegal merupakan salah satu workshop hidromekanikal yang memiliki spesialisasi dibidang hidromekanikal dan menjadi pendukung fabrikasi dan instalasi Divisi Sumber Daya Air. Workshop ini berfokus pada pekerjaan mekanikal untuk bangunan air seperti pipa penstock, katup dan trashrack pada bendungan-bendungan, pintu air pada bendungan serta pompa pengendali banjir. Penelitian ini berjudul "Pengaruh Kuat Arus Terhadap Kekuatan Tarik Pada Proses Pengelasan Baja SM 400 B Menggunakan Proses Pengelasan SMAW Di PT Barata Indonesia (Persero) Divisi Sumber Daya Air-Tegal”. Tujuan penelitian ini adalah untuk mengetahui pengaruh kuat arus terhadap kekuatan tariknya serta mengetahui cacat las yang diakibatkan oleh kuat arus yang tidak sesuai dengan welding procedure specification (WPS). Adapun metode pengujian adalah pertama mencari literatur-literatur penunjang, selanjutnya adalah pengumpulan data lapangan, kemudian menganalisis data. Adapun pengelasan dilakukan dengan metode SMAW dengan material berupa baja SM $400 \mathrm{~B}$, dan elektroda E 7016 dengan diameter 3,2. Berdasarkan penelitian yang telah dilakukan diketahui bahwa semakin besar kuat arusnya maka akan semakin besar nilai kekuatan tariknya begitupun sebaliknya semakin kecil kuat arusnya maka semakin kecil pula nilai kekuatan tariknya. Selain itu, kuat arus harus sesuai dengan WPS. Jika arus pengelasan tidak sesuai WPS, maka akan terjadi cacat pengelasan. Arus pengelasan yang terlalu rendah akan menyebabkan cacat las berupa undercut, cacat las spatter, sedangkan arus pengelasan yang terlalu tinggi akan menyebabkan cacat las berupa porositas, incomplete peneration.

Kata kunci: Pengelasan, Kuat Arus, Kuat Tarik, Cacat.

\begin{abstract}
PT. Barata Indonesia (Persero) Tegal Water Resources Division is one of the hydromechanical workshops that specializes in hydromechanical and supports the fabrication and installation of the Water Resources Division. This workshop focuses on mechanical work for water structures such as penstock pipes, valves and trashracks in dams, sluice gates in dams and flood control pumps. This research is entitled "Effect of Strong Current on Tensile Strength in SM 400 B Steel Welding Process Using SMAW Welding Process at PT Barata Indonesia (Persero) Water Resources Division-Tegal". The purpose of this study was to determine the effect of current strength on tensile strength and to determine welding defects caused by currents that are not in accordance with the welding procedure specification (WPS). The test method is first to look for supporting literature, next is to collect field data, then analyze the data. The welding is carried out using the SMAW method with the material in the form of SM 400 B steel, and electrodes $E$ 7016 with a diameter of 3.2. Based on the research that has been done, it is known that the greater the current, the greater the value of the tensile strength, and vice versa, the smaller
\end{abstract}


Journal Of Metallurgical Engineering And Processing Technology, Vol. 2,

N0. 2, February 2022, pp.39-46

P-ISSN: 2723-6854, E-ISSN: 2798-1037

the current, the smaller the value of the tensile strength. In addition, the current strength must match the WPS. If the welding current does not match the WPS, a welding defect will occur. Welding currents that are too low will cause welding defects in the form of undercuts, welding spatter defects, while welding currents that are too high will cause welding defects in the form of porosity, incomplete penetration.

Keyword: Welding, Current Strength, Tensile Strength, Defect.

\section{Pendahuluan}

Pengelasan (welding) adalah teknik penyambungan logam dengan cara mencairkan sebagian logam induk dan logam pengisi dengan atau tanpa logam penambah dan menghasilkan logam kontinyu (Siswanto, 2011). Berdasarkan definisi dari American Welding Society (AWS) las adalah ikatan metalurgi pada sambungan logam atau logam paduan yang dilaksanakan dalam keadaan lumer atau cair. Secara singkat, dapat dijabarkan bahwa proses pengelasan merupakan sambungan dari beberapa batang logam dengan menggunakan energi panas. Pada pengelasan, suhu yang digunakan antara 1500 hingga 1600 derajat Celcius.

Pengelasan shield metal arc
welding merupakan teknik
pengelasan yang di kelompokan ke
dalam teknik r pengelasan
menggunakan busur gas dan fluk. Pada teknik pengelasan ini bahan atau material logam penyambung (elektroda) berupa logam yang telah dilapisi oleh fluks (slag las). Lapisan ini berfungsi untuk melindungi logam dari gas oksidasi luar (Mizhar susri et al, 2014). Pada proses pengelasan logam dengan teknik pengelasan shield metal arc welding (SMAW) kuat arus listrik yang digunakan dalam proses penyambungan logam merupakan indikator penting yang perlu di perhatikan. Hal ini di karenakan kuat arus listrik menentukan besarnya panas yang di hasilkan dari busur listrik pada nyala di ujung electode yang digunakan.

Penstock termasuk salah satu produk dari PT. Barata Indonesia. Penstock adalah saluran atau terowongan yang menghubungkan bak penampung air dari Bendungan ke turbin di gedung pembangkit listrik ataupun ke saluran irigasi untuk pertanian.

Pada proses pengolahannya, PT Barata Indonesia (persero) Tegal memiliki 11 jalur. Jalur 1 dan 2 adalah tempat untuk melakukan marking plat dan tempat pemotongan (cutting) material. Jalur 3 digunakan untuk penyimpanan material-material profil, plat serta penempatan alat-alat berat seperti mesin $\mathrm{CNC}$, mesin giling tebu dan mesin bubut. Jalur 4 digunakan untuk tempat menaruh material-material utama dan proses yang ada di area ini adalah proses pembubutan, proses pengeboran serta proses perakitan konstruksi atas. Jalur 5 dikhususkan untuk proses permesinan. jalur 6 digunakan untuk proses welding, proses gerinda, proses fit up, tempat pengujian stang grad, housing, proses pengeboran dan proses pembubutan. Jalur 7 digunakan untuk proses pengeboran komponen kecil, penyetelan daur pintu, assembling pintu kecil. jalur 8 digunakan untuk proses bending plat, penyetelan mini jet flow, proses pengeboran komponen kecil, proses fit up frame, penyetelan pintu besar 
Journal Of Metallurgical Engineering And Processing Technology, Vol. 2,

N0. 2, February 2022, pp.39-46

P-ISSN: 2723-6854, E-ISSN: 2798-1037

dan proses pembuatan frame serta tempat penyimpanan penstock. Jalur 9 digunakan untuk proses pelurusan material dan proses penyetelan frame. jalur 10 digunakan proses painting sedangkan jalur 11 digunakan untuk proses painting dan sand blasting.

Baja SM 400 merupakan baja berstandar JIS G3106, termasuk hot rolled carbon steel plate yang digunakan untuk material pengelasan struktural. SM 400 A/B/C memiliki komposisi yang berbeda, komposisi kimia baja SM 400 dapat dilihat pada Tabel 1.

Tabel 1. Komposisi Kimia Baja SM 400

\begin{tabular}{|c|c|c|c|c|c|}
\hline \multirow{2}{*}{ Symbol } & \multicolumn{5}{|c|}{ Chemical Composition } \\
\cline { 2 - 6 } & C Max & Si Max & Mn & P Max & S Max \\
\hline $\begin{array}{c}\text { SM 400 } \\
\text { A }\end{array}$ & 0.23 & - & $\begin{array}{c}2.5 \times \text { C } \\
\text { min }\end{array}$ & 0.035 & 0.035 \\
\hline $\begin{array}{c}\text { SM 400 } \\
\text { B }\end{array}$ & 0.20 & 0.35 & $0.6-1.40$ & 0.035 & 0.035 \\
\hline $\begin{array}{c}\text { SM 400 } \\
\text { C }\end{array}$ & 0.19 & 0.35 & $1.4 \max$ & 0.035 & 0.035 \\
\hline
\end{tabular}

Sumber : JIS Handbook, 2010

Baja SM 400 A/B/C diaplikasikan untuk plat, bar, atau bentuk lain. Memiliki kualitas struktural untuk di rivet, di bolt, atau di las pada jembatan dan bangunan, serta untuk struktural umum. Baja SM 400 memiliki ketebalan yang berbeda sesuai dengan kelasnya dapat dilihat pada Tabel 2.

Tabel 2. Designation of Grade dan Applicable Thickness pada Baja SM 400

\begin{tabular}{|c|l|c|}
\hline $\begin{array}{c}\text { Designation } \\
\text { of Grade }\end{array}$ & \multicolumn{1}{|c|}{ Steel Product } & $\begin{array}{c}\text { Applicable } \\
\text { Thickness } \\
\text { (mm) }\end{array}$ \\
\hline SM 400 A & $\begin{array}{l}\text { Steel plate, steel strip in coil, } \\
\text { section, and flat }\end{array}$ & $\leq 200$ \\
\hline SM 400 B & $\begin{array}{l}\text { Steel plate, steel strip in coil, } \\
\text { section, and flat }\end{array}$ & $\leq 200$ \\
\hline \multirow{2}{*}{ SM 400 C } & $\begin{array}{l}\text { Steel plate, steel strip in coil, } \\
\text { and section }\end{array}$ & $\leq 100$ \\
\cline { 2 - 3 } & Flat & $\leq 50$ \\
\hline
\end{tabular}

Sumber : JIS Handbook, 2010
Selain itu, Baja SM juga memiliki sifat mekanik berupa yield point dan tensile strength yang berbeda sesuai kelasnya. Sifat mekanik baja SM dapat dilihat pada Tabel 3.

Tabel 3. Mechanical Properties Baja SM 400

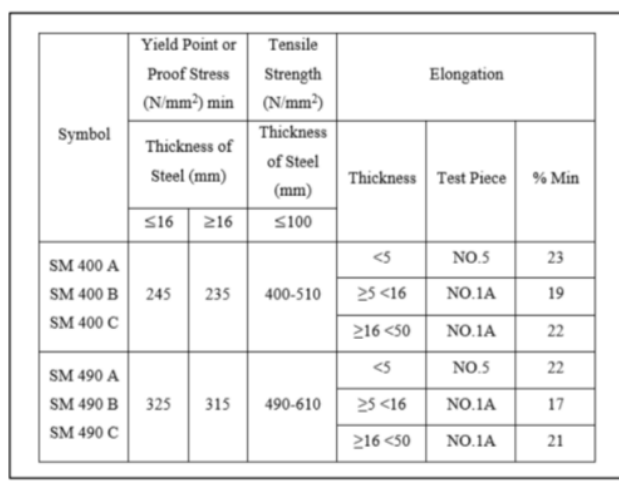

Sumber : JIS Handbook, 2010

Kekuatan tarik adalah salah satu sifat mekanik yang sangat penting dan dominan dalam suatu perancangan konstruksi dan proses manufaktur. Setiap material atau bahan memiliki sifat (kekerasan, kelenturan, dan lain lain) yang berbeda-beda. Uji tarik adalah salah satu uji stress strain mekanik yang bertujuan untuk mengetahui kekuatan bahan terhadap gaya tarik.

Dengan menarik suatu bahan sampai putus maka dapat diketahui bagaimana suatu bahan tersebut bereaksi terhadap gaya tarik dan mengetahui sejauh mana material itu bertambah panjang (Wiryosumarto, 2000). Penarikan gaya terhadap beban akan mengakibatkan terjadinya perubahan bentuk (deformasi) bahan tersebut. Proses terjadinya deformasi pada bahan uji adalah proses pergeseran butiran kristal logam yang di akibatkan melemahnya gaya elektro magnetik setiap atom logam hingga terlepas ikatan tersebut oleh penarikan gaya maksimum (Mizhar susri et al, 2014). 
Journal Of Metallurgical Engineering And Processing Technology, Vol. 2,

N0. 2, February 2022, pp.39-46

P-ISSN: 2723-6854, E-ISSN: 2798-1037

Rumus untuk mencari tegangan dapat di lihat di bawah ini :

$$
\varepsilon=\frac{L-L o}{L o}=\frac{\Delta L}{L o}=\frac{F}{A o}
$$

Keterangan :

$\Sigma=$ tegangan tarik $(\mathrm{N} / \mathrm{mm} 2)$

$\mathrm{L}=$ panjang spesiment setelah patah $(\mathrm{mm})$

Lo $=$ panjang spesiment mula-mula $(\mathrm{mm})$

$\mathrm{F}=$ beban $(\mathrm{N})$

Ao $=$ luas penampang

atau dengan rumus berikut ini :

$$
S_{U}=\frac{p_{\text {maks }}}{A_{0}}
$$

Keterangan :

$\mathrm{Su}=$ Kuat tarik

Pmaks = Beban maksimum

Ao $\quad=$ Luas penampang awal

\section{Metodologi Penelitian}

Material :

a. Baja SM 400 B

b. Elektroda

\section{Metode}

\section{Pengelasan SMAW}

a. Membersihkan pelat yang akan dilas. Lalu menempatkan pelat tersebut di lantai.

b. Tempatkan massa mesin las pada salah satu bahan yang akan dilas. Lalu tambahkan elektroda pada panel penjepit elektroda di mesin las.

c. Sesudah bahan siap untuk di las, perlahan-lahan dekatkan ujung elektroda pada bahan yang akan dilas.

d. Perlahan-lahan gerakkan elektroda ke sepanjang ruang yang dilas.

e. Sesudah selesai, bersihkan kerak yang menutupi sisi yang dilas dengan memakai palu.

\section{Pengujian Tarik}

a. Menyiapkan specimen

b. Pembuatan gauge length

c. Pengukuran dimensi

d. Pengujian pada mesin uji tarik

- Catat data mesin pada lembar kerja.

- Ambil kertas milimeter dan pasang pada tempatnya.

- Ambil spesimen dan letakkan pada tempatnya secara tepat.

- Setting beban dan pencatat grafik pada mesin tarik.

- Berikan beban secara kontinyu sampai spesimen patah.

- Catat besarnya beban pada saat ultimate dan ketika patah yang nilainya tampak pada monitor beban

Adapun flowchart yang digunakan dalam kerja praktek ini adalah sebagai berikut.

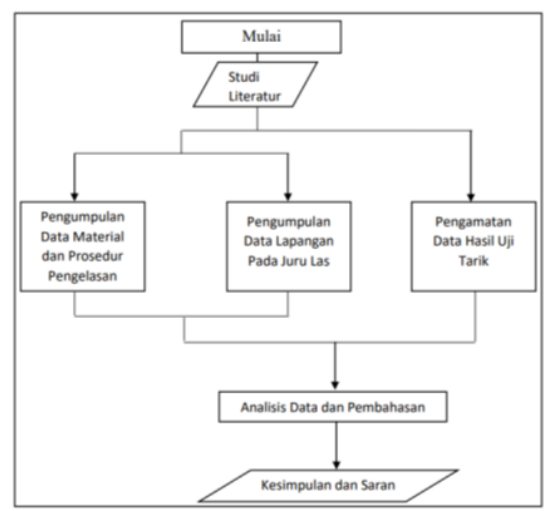

Gambar 1. Flowchart Kerja Praktek

\section{Pembahasan}

Dalam penelitian ini, penulis melakukan pengamatan dan pengambilan data di PT Barata Indonesia guna mengetahui proses pengelasan SMAW. Kualitas pengelasan pengaruhi oleh kuat arus yang akan berkaitan dengan kuat tarik serta cacat yang diakibatkan oleh ketidaksesuaian kuat arus. 
Journal Of Metallurgical Engineering And Processing Technology, Vol. 2,

N0. 2, February 2022, pp.39-46

P-ISSN: 2723-6854, E-ISSN: 2798-1037

Dari penelitian dapat terlihat bahwa semakin tinggi kuat arus pengelasan maka semakin besar kuat tariknya, dan jika kuat arus terlalu rendah ataupun terlalu tinggi akan menyebabkan cacat hasil pengelasan. Berikut merupakan analisis dari penelitian di atas.

\section{Proses Pengelasan SMAW}

\begin{abstract}
Langkah yang dilakukan pertama dalam proses pengelasan SMAW adalah membersihkan pelat yang akan dilas. Lalu menempatkan pelat tersebut di meja. Tempatkan massa mesin las pada salah satu bahan yang akan dilas, lalu tambahkan elektroda pada panel penjepit elektroda di mesin las. Pemilihan elektroda ini tergantung oleh bahan/ material yang digunakan. Selain itu ketebalan pelat juga mempengaruhi seberapa besar diameter elektroda yang digunakan. Kuat arus yang digunakan sesuai dengan kawat yang digunakan/ tebal pelat yang dipakai dan melihat rentang kuat arus pada WPS.
\end{abstract}

Sesudah bahan siap untuk di las, perlahan-lahan dekatkan ujung elektroda pada bahan yang akan dilas. Jarak di antara ujung elektroda dengan bahan yang akan dilas sangat memengaruhi kualitas pengelasan. Bila jarak begitu jauh, akan muncul percikan seperti hujan bintik-bintik api. Proses pengelasan pun tidak prima. Bila jarak begitu dekat, api tidak menyala dengan sempurna. Serta tidak ada jarak yang cukup untuk tempat lelehan elektroda. Jarak yang baik yaitu seperdelapan dari tebal elektroda. Perlahan-lahan gerakkan elektroda ke sepanjang ruang yang dilas. Hasil yang baik waktu pengelasan bisa dilihat di atas permukaan yang dilas berupa seperti gelombang rapat dan teratur ditutup dengan sempurna sisi yang dilas. Jika belum sempurna, maka harus mengulangi pengelasan pada sisi yang belum tersatukan dengan baik tersebut. Pada beberapa kasus, bahan yang telah dilas harus di gerinda bila pengelasan tidak sempurna.

\section{Pengaruh Kuat Arus Pengelasan Terhadap Kekuatan Tarik}

Kuat arus pengelasan sangat berpengaruh terhadap kualitas hasil pengelasan dan juga terhadap kuat tariknya. Pada penelitian ini dilakukan pengujian tarik dengan menggunakan variabel arus yang berbeda untuk mengetahui pengaruh kuat arus pengelasan terhadap kuat tariknya. Kuat arus listrik yang digunakan sebesar 90 Amper, 100 Amper, 110 Amper. Hasil pengujian tarik masing- masing variasi arus dapat dilihat pada Tabel 4 dan grafik peningkatan kuat tarik yang diakibatkan oleh kuat arus dapat dilihat pada Gambar 2.

Tabel 4. Hasil Uji Tarik

\begin{tabular}{|c|c|c|c|c|}
\hline \multirow{4}{*}{ 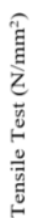 } & \multirow{2}{*}{ Sampel } & \multicolumn{3}{|c|}{ Kuat Arus } \\
\hline & & 90 & 100 & 110 \\
\hline & 1 & 434,78 & 449,58 & 451,59 \\
\hline & 2 & 434,96 & 438,68 & 466,88 \\
\hline
\end{tabular}

Pada spesiment test pengelasan yang di beri perlakuan variasi arus pengelasan sebesar 90 amper, hasil uji tarik menunjukan pada sampel pertama di dapatkan nilai tegangan maksimum (Ultimate Tensile Strength) yaitu sebesar 434.78 $\mathrm{N} / \mathrm{mm}^{2}$, dan pada sampel ke dua di dapatkan nilai UTS (Ultimate Tensile Strength) sebesar $434.96 \mathrm{~N} / \mathrm{mm}^{2}$, dari 2 pengulangan pada spesiment test 
Journal Of Metallurgical Engineering And Processing Technology, Vol. 2,

N0. 2, February 2022, pp.39-46

P-ISSN: 2723-6854, E-ISSN: 2798-1037

dengan perlakuan variasi arus pengelasan sebesar 90 amper di dapatkan nilai rata-rata UTS nya sebesar $434.87 \mathrm{~N} / \mathrm{mm}^{2}$.

Pada spesiment test pengelasan dengan perlakuan variasi arus pengelasan sebesar 100 Amper, hasil uji tarik menunjukan pada sampel pertama di dapatkan nilai tegangan maksimum (Ultimate Tensile Strength) yaitu sebesar 449.58 $\mathrm{N} / \mathrm{mm}^{2}$, dan pada sampel ke dua di dapatkan nilai UTS (Ultimate Tensile Strength) sebesar $438.68 \mathrm{~N} / \mathrm{mm}^{2}$, dari 2 pengulangan pada spesiment test dengan perlakuan variasi arus pengelasan sebesar 100 Amper di dapatkan nilai rata-rata UTS nya sebesar $444.13 \mathrm{~N} / \mathrm{mm}^{2}$.

Selanjutnya pada spesiment test pengelasan dengan perlakuan variasi arus pengelasan sebesar 110 Amper, hasil uji tarik menunjukan pada sampel pertama di dapatkan nilai tegangan maksimum (Ultimate Tensile Strength) yaitu sebesar 451.59 $\mathrm{N} / \mathrm{mm}^{2}$, dan pada sampel ke dua di dapatkan nilai UTS (Ultimate Tensile Strength) sebesar $466.88 \mathrm{~N} / \mathrm{mm}^{2}$, dari 2 pengulangan pada spesiment test dengan perlakuan variasi arus pengelasan sebesar 110 Amper di dapatkan nilai rata-rata UTS nya sebesar $459.235 \mathrm{~N} / \mathrm{mm}^{2}$.

Dari grafik hasil pengujian tarik dapat dilihat bahwa semakin tinggi arus pengelasan maka kekuatan tariknya semakin meningkat. Pada hal ini variasi kuat arus pengelasan sangat berpengaruh pada kekuatan tarik suatu material. Dimulai dari rapuh, yakni pada kuat arus yang sangat rendah. Pada tahap ini, akibat kuat arus yang sangat rendah mengakibatkan ukuran butir mengecil sehingga jarak antar butir semakin jauh, ikatan melemah, dan rapuh. Dengan demikian material amat mudah patah, sehingga energi yang dibutuhkan untuk menarik dan mematahkannya sangat kecil pula. Selanjutnya dengan bertambahnya kuat arus pengelasan, maka ukuran butir makin membesar sehingga jaraknya semakin dekat dan ikatannya menguat serta kekuatan tarik dan ketangguhannya meningkat, namun masih getas.

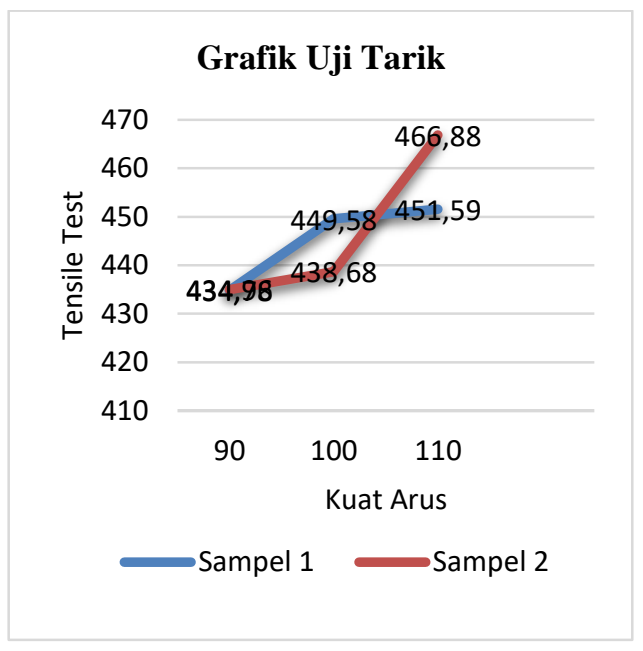

Gambar 2. Grafik Uji Tarik

Sumber : PT.Barata Indonesia Tegal

\section{Cacat Pada Pengelasan}

Cacat las adalah hasil pengelasan yang tidak memenuhi syarat keberterimaan yang sudah dituliskan di standart (ASME IX, AWS). Salah satu faktor yang dapat menyebabkan cacat pada pengelasan adalah kuat arusnya. Dalam hal ini kuat arus harus sesuai dengan acuan yaitu sesuai dengan welding procedure specification (WPS).

Jika kuat arus terlalu tinggi maka akan menimbulkan cacat pada hasil pengelasan. Cacat yang terbentuk adalah cacat las undercut, cacat las spatter. Cacat las undercut adalah sebuah cacat las yang berada di 
Journal Of Metallurgical Engineering And Processing Technology, Vol. 2,

N0. 2, February 2022, pp.39-46

P-ISSN: 2723-6854, E-ISSN: 2798-1037

bagian permukaan atau akar, bentuk cacat ini seperti cerukan yang terjadi pada base metal atau logam induk. Cacat over spatter adalah percikan las, sebenarnya jika spater dapat dibersihkan maka tidak termasuk cacat. Namun jika jumlahnya berlebih dan tidak dapat dibersihkan maka dikategorikan dalam cacat visual.

Jika kuat arus terlalu rendah maka akan menimbulkan cacat pada hasil pengelasan. Cacat yang terbentuk adalah cacat porositas, incomplete penetration. Cacat Porositas adalah sebuah cacat pengelasan yang berupa sebuah lubang lubang kecil pada weld metal (logam las), dapat berada pada permukaan maupun didalamnya. Cacat incomplete fusion adalah sebuah hasil pengelasan yang tidak dikehendaki karena ketidaksempurnaan proses penyambungan antara logam las dan logam induk.

\section{Kesimpulan}

Berdasarkan hasil analisa terkait pengaruh kuat arus terhadap kekuatan tarik PT Barata Indonesia dapat disimpulkan :

a. Proses pengelasan SMAW diawali dengan membersihkan pelat yang akan dilas, lalu menempatkan pelat tersebut di lantai atau di meja. Tempatkan massa mesin las pada salah satu bahan yang akan dilas, lalu tambahkan elektroda pada panel penjepit elektroda di mesin las. Sesudah bahan siap untuk di las, perlahan-lahan dekatkan ujung elektroda pada bahan yang akan dilas. Perlahan-lahan gerakkan elektroda ke sepanjang ruang yang dilas. Sesudah selesai, bersihkan kerak yang menutupi sisi yang dilas dengan memakai palu. Lalu memeriksa kembali apakah ada sisi yang belum sempurna. Jika belum sempurna, maka harus mengulangi pengelasan pada sisi yang belum tersatukan dengan baik tersebut.

b. Semakin tinggi kuat arus yang digunakan pada pengelasan baja SM 400 B maka semakin besar hasil uji kuat tariknya. Pada penelitian ini didapatkan rata-rata kuat tarik tertinggi yaitu sebesar $459.235 \mathrm{~N} / \mathrm{mm}^{2}$ dengan kuat arus sebesar $110 \mathrm{~A}$, sedangkan ratarata kuat tarik terendah yaitu sebesar $434.87 \mathrm{~N} / \mathrm{mm}^{2}$ dengan kuat arus sebesar $90 \mathrm{~A}$.

c. Kuat arus terlalu tinggi menyebabkan adanya cacat undercut dan over spatter, sedangkan kuat arus terlalu rendah menyebabkan adanya cacat porositas dan incomplete fusion.

\section{Ucapan Terimakasih}

Penelitian ini dapat dilakukan dengan baik berkat adanya bantuan dari berbagai pihak. Untuk itu penulis mengucapkan terimakasih kepada :

1. PT Barata Indonesia (Persero) Tegal.

2. Bapak Anton Sudiyanto sebagai dosen pembimbing dalam penulisan jurnal ini.

3. Bapak Dicnanda Wildan Saputra selaku pembimbing dari PT Barata Indonesia (Persero) Tegal.

4. Berbagai pihak yang telah ikut berpartisipasi membantu kelancaran kegiatan penelitian, baik secara langsung maupun tidak langsung. 
Journal Of Metallurgical Engineering And Processing Technology, Vol. 2,

N0. 2, February 2022, pp.39-46

P-ISSN: 2723-6854, E-ISSN: 2798-1037

\section{Daftar Pustaka}

Bintoro, G.A. 1999. Dasar-Dasar

Pekerjaan Las Jilid

1.Yogyakarta: Penerbit Kanisius.

Yogyakarta.

Muhroni, A.,S \& Kembaren B. H.

2013. Pengaruh Variasi

Kecepatan dan Kuat Arus

Terhadap Kekerasan, Tegangan

Tarik, Struktur Mikro Baja

Karbon Rendah Dengan

Elektroda E6018. Jurnal

Rekayasa Mesin Vol.13 No.1

Prayitno, D., \& Hutagalung, H. D. 2018. Pengaruh Kuat Arus Listrik Pengelasan Terhadap Kekerasan Lapisan Las. Jurnal Dinamika Vokasi Teknik Mesin Vol.1 No.1 (1-6)

Trinova Budi Santoso, Solichin, Prihanto Tri Hutomo, (2015), Pengaruh Kuat Arus Listrik Pengelasan Terhadap Kekuatan Tarik Dan Struktur Mikro Las Smaw Dengan Elektroda E7016, Jurnal Teknik Mesin, Tahun 23, No. 1, April 2015, Hal 59- 64 